Information for citation:

Eyrian G. N. Prava pol'zovatelya zemel'nogo uchastka na podzemnoe prostranstvo [The Land Parcel User's Right to the Underground Space]. Vestnik Permskogo Universiteta. Juridicheskie Nauki - Perm University Herald. Juridical Sciences. 2017. Issue 38. Pp. 535-547. (In Russ.). DOI: 10.17072/1995-4190-2017-38-535-547.

UDC 349.412 .3

DOI: 10.17072/1995-4190-2017-38-535-547

\title{
THE LAND PARCEL USER'S RIGHT TO THE UNDERGROUND SPACE
}

\author{
G. N. Eyrian \\ Perm State University \\ 15, Bukireva st., Perm, 614990, Russia \\ ORCID: 0000-0002-3024-6816 \\ ResearcherID: F-7623-2016 \\ e-mail: grazhdanskoe.pravo@gmail.com
}

Introduction: the article analyses the legal regulation of the underground space use. The regulation of this issue by standards of different branches of legislation is based on various approaches to classification of "underground space", mineral resources, groundwater as objects of legal regulation, as well as to the procedure for their use. Therefore, the current legislation in this area requires a complex analysis. Purpose: to develop an understanding of the spatial boundaries of a land parcel with regard to its legal user's powers to use the underground space. Methods: the author used the system approach, methods of comparison, description and interpretation, theoretical methods of formal and dialectical logic, specific scientific methods, such as comparative law, historical legal ones and the method of interpreting legal rules. Results: the current law embodies different approaches to defining the rights of a land parcel user: the civil law approach, based on the principle cujus est solum, and the natural resource approach, providing access to natural resources based on the right to common natural resources management. Conclusions: Notwithstanding the fundamental changes in the regulation of property relations after the collapse of the Soviet Union, the relations under study have not been considerably changed. There is still differentiation of land plots and subsoil according to the purposes (types) of use, which implies a possibility to classify underground space both as a land parcel and as subsoil. Moreover, in relation to widespread mineral resources, groundwater, and space used for construction of underground facilities the current legislation follows the approach that was formed in the Soviet period: the specified objects constitute subsoil as an object of the public property right, which the state allows to be used for certain purposes by lawful users of land plots.

Keywords: land parcel; widespread mineral resources; groundwater; construction of underground facilities

\section{Information in Russian}

\section{ПРАВА ПОЛЬЗОВАТЕЛЯ ЗЕМЕЛЬНОГО УЧАСТКА НА ПОДЗЕМНОЕ ПРОСТРАНСТВО}

\section{Г. Н. Эйриян}

кандидат юридических наук, доцент кафедры гражданского права Пермский государственный национальный исследовательский университет 614990, Россия, г. Пермь, ул. Букирева, 15

ORCID: 0000-0002-3024-6816

ResearcherID: F-7623-2016

e-mail: grazhdanskoe.pravo@gmail.com 
Введение: в статье анализируется нормативно-правовое регулирование использования подземного пространства. Регламентация данного вопроса нормами разных отраслей законодательства базируется на различных подходах к квалификачии «подземного пространства», полезных ископаемых, подземных вод в качестве объекта правового регулирования, а также порядку их использования, что требует комплексного анализа действующего законодательства в этой части. Цель: сформировать представление о пространственных пределах земельного участка в части правомочий его законного пользователя по использованию подземного пространства. Методы: системный подход, методы сравнения, описания, интерпретации; теоретические методы формальной и диалектической логики. Применялись частнонаучные методы: сравнительно-правовой, историко-правовой и метод толкования правовых норм. Результаты: в действующем законодательстве нашли отражение разные подходы к определению прав пользователя земельного участка на подземное пространство: иивилистический, базирующийся на принципе cujus est solum, и природоресурсовый, обеспечивающий доступ к природным ресурсам на основе права общего природопользования. Выводы: несмотря на кардинальные изменения в регулировании имущественных отномений, произошедших после распада СССР, анализируемые отношения не подверглись существенным изменениям. Сохраняется дифференциация земельных участков и недр по иелям (видам) использования, что влечет возможность квалификации подземного пространства как в качестве земельного участка, так и в качестве недр. Кроме того, в отномении общераспространенных полезных ископаемых, подземных вод, пространства для строительства подземных сооружений действующее законодательство сохраняет подход, который сформировался еще в советский период времени: указанные объекты составляют недра как объект права государственной собственности, которые государство разрешает использовать в определенных целях законным пользователям земельных участков.

Ключевые слова: земельный участок; общераспространенные полезные ископаемые; подземные воды; строительство подземных сооружений

\section{Introduction}

The use of land parcel is rarely limited to an impact onto its surface. A. L. Borovikovskiy, a prerevolution researcher, drew attention to this peculiarity, and, in his opinion: "the land "possession and use" assume necessary not only a contact with its surface in the mathematical sense of this word, but some deepening into it" [4, p. 82, 83]. He illustrated his position with the following examples: one cannot get the harvest without seeds penetrating to a certain deeper layer of the soil; construction foundations go deep into the ground, etc.

"Where is the depth level located where the land surface ends and the subsoil begins? Where is that plane about which we can say that the surface is above it, and the subsoil is underneath it?" [4, p.83]. Modern scientists are bewildered and are looking for an answer to these questions. Kamyshanskiy V. P. deems it fair that "not only a "land parcel" and a "subsoil plot" as objects of civil rights require a more precise definition, but the procedure for defining borders between them and possible limits of penetration of a landowner into subsoil under the parcel, and vice versa. This issue is not much about geometry (the land is a rich soil layer, and the subsoil is everything that can be found underneath), but it rather falls within the law. For example, roots of perennial trees located on a landowner's parcel penetrate considerably deeper than the rich soil layer is, and one can ask what it is: a result of exercise of land title or the use of subsoil located underneath the land parcel?" [7].

The complexity of the answer to the question of land parcel user's rights ${ }^{1}$ to underground space is conditioned by the intersectoral nature of legal regulation of matters under analysis. The current legislation contains rules of use of underground space that may apply to three branches of legislation

\footnotetext{
${ }^{1}$ The land parcels owners, land users, landholders and leaseholders are understood as the users of land parcels within the frames of this article.
} 
as minimum: civil, land and mining, and these rules are not always in tune.

The RF Civil Code establishes that a landowner has a right to use, at his own and sole discretion, everything that is above and beneath the surface of that parcel, unless otherwise provided by the Subsoil Law, on airspace management, and other laws, and does not infringe the rights of other parties (Clause 3, Article 261) ${ }^{1}$. The given provision is obviously based on the Roman principle cujus est solum, which is not in operation anymore nowadays by virtue of provisions of the Subsoil $\mathrm{Law}^{2}$.

As it was stated by the RF Constitutional Court in one of its rulings "...the subsoil as a part of the crust is not being the part of land parcel (earth surface), but is owned by the state and acts as an independent object of civil rights". Hence, $a$ land parcel owner possesses no rights to subsoil underneath ${ }^{3}$.

Considering provisions of Art. 1.2 of the Subsoil Law that attribute underground space and mineral deposits, energy and other resources contained in the subsurface to the subsoil as an object of state property, it would be appropriate to conclude that a land parcel owner has rights neither to underground space nor to the use of resources in it.

However, it is not right. Users of land parcels have the right to use both underground space and resources in it according to the procedure of subsoil use, and within certain limits, which is expressly provided for in provisions of land and mining legislation.

The RF Land Code regulates the right of landowners, land users, landholders and land tenants, with the latter being provided with the right to use widespread mineral deposits, fresh groundwater found on the land parcel for own needs in compli-

\footnotetext{
${ }^{1}$ The Civil Code of the Russian Federation (Part 1): RF Federal Law of Nov. 30, No. 51-FZ (version of July 26, 2017). Corpus of Legislative Acts of the Russian Federation. 1994. No. 32, Art. 3301.

${ }^{2}$ Law on subsoil: RF Federal Law of 21.02.1992 No. 2395-1 (version of 26.07.2017). Rossiyskaya gazeta - Russian Gazette. 1992. No. 102.

${ }^{3}$ On refusal to accept for consideration a complaint of Kirpichnyi Ltd. and Khalenkov Arthur Vasilievich, a citizen, of abuse of constitutional rights and freedoms with part 4 of Article 7 of the Russian Federation Law "On Subsoil": Determination of the RF Constitutional Court of 24.06.2014 No. 1314-O [Electronic resource]. Access from "ConsultantPlus".
}

ance with the established procedure (Clause 1 Article 40, Clause 1 Article 41) $)^{4}$.

Article 19 of the RF Subsoil Law states that within the boundaries of the considered land and with no blasting works land parcels owners, land users, landholders, land tenants are entitled to use for their own needs widespread mineral deposits which may be available within the land boundaries and which are not in the State Register of Mineral Reserves, groundwater which extraction volume should not exceed $100 \mathrm{~m}^{3}$ per day from waterbearing beds not being a source of centralized water supply or located above the water-bearing beds or from water-bearing beds being a source of centralized water supply, and to make construction of underground facilities to the depth of up to 5 meters pursuant to the procedure established by the law and other legislative instruments of the constituents of the Russian Federation.

Moreover, land users have the right to use underground space, but not according to the procedure of the use of subsoil, but of land parcel, which will be discussed below. This conclusion is based on the differentiation between land parcel and subsoil not only by the geometrical "dimensional" criterion, but also in a functional sense.

\section{Land Parcel and Subsoil: Correlation of Concepts}

The legal literature contains different opinions on correlation of a land parcel and subsoil as objects of civil transactions. Noting complexity in identification of boundaries between land parcel and subsoil, A. P. Anisimov and S. A. Charkin think that according to the general rule the boundary between land and subsoil makes up 5 meters (Art. 19 of the Federal Subsoil Law) [1].

According to V. A. Lapach, the soil layer is a kind of the boundary separating the "land" from the soil $[9$, p. 318]. He grounds his opinion on the definition of subsoil provided for in the Subsoil Law of February 21, 1992. He believes that the issue of the subsoil and land parcel delimitation could be

\footnotetext{
${ }^{4}$ Land Code of the Russian Federation: RF Federal Law of Oct. 25, 2001 No. 136-FZ (version of July 29, 2017). Corpus of Legislative Acts of the Russian Federation. 2001. No.44, Art. 4147.
} 
resolved by establishing the dimensional-quality boundaries of the soil layer [9, p. 317].

Some authors deny the principle possibility of subsoil qualification as an independent object of transactions. So, K. S. Kalinichenko in his thesis research asserts that "the effective Russian subsoil legislation does not allow to determine where the boundary between land parcel and subsoil underneath passes" $[6$, p. 9]. It is the author's opinion that the subsoil block should not be recognized as an independent subject of the right and should be treated as a land parcel.

M. A. Dimitiriev has a similar point of view. In his opinion, “...the subsoil plot by its characteristics is a component of the land parcel" [5]. He believes that "... speaking about the subsoil plot, we have to speak not about a separate object of civil rights, but about specific real right for the use of land parcel to the extent of mineral deposits laid in its subsoil and another necessary utilization (subsurface rights)" [5].

The above-mentioned opinions about the subsoil and land parcel correlation are based completely on a dimensional characteristic, which is traditional for individualization of objects of civil law right. This approach entails impossibility to define clear legal boundaries of the land parcel and subsoil and, as a result, leads either to the idea of refusal from subsoil qualification as an independent subject of the right or the necessity of looking for another criterion for differentiation of the terms under analysis.

In this regard, arguments of pre-revolution researchers are demonstrative. Analysing the evolution of the Russian law on natural resources development, V. Udintsjev asked the questions: "What is subsoil? Does it exist as a certain item that can be seen, felt, or at least to be thought as having certain appearance, shape, height, etc.? Obviously, it does not" $[10$, p. 32]. He believed that it is impossible to establish the ownership right to an object, which due to its uncertainty and endlessness has no physical ability to appear in civil transactions [10, p. 33]. Denying the possibility of subsoil qualification as an independent item of transactions, and the rights to subsoil as a real right, at the same time, he acknowledged as evidence that the earth interior has economic benefit [10, p. 37].

A. L. Borovikovskiy supported another approach - a possibility to qualify subsoil and land parcel as independent subjects of the right. He be- lieved that there is no any exterior characteristic to make differentiation between those concepts, and "the depth had nothing to do there", so another substantial characteristic should be looked for. In his opinion, subsoil and land parcel are differentiated only by the nature of use. The earth interior is about its composition, content. Meanwhile I use the possible benefits from the earth without exhausting its essence, it does not matter how deep I penetrate, I just use its "surface". However, when I use the soil, I work with the earth interior [4, p. 84].

As a result of such approach to the subsoil and land parcel delimitation the following assertion was formed: "the plant is a product of the earth not only in the part which is above the soil, but with its roots which sometimes penetrate considerably deeper into the soil. The foundations of constructions sit deep in the ground; cellars go even deeper; wells produce water from significant depth often. Nevertheless, such deepening is accommodated quite well in the concept of possession and use of the earth surface, but not of its subsoil" [4, p. 83].

G. S. Bashmakov, while analysing the concept of subsoil according to the Soviet law, criticized the approach of A. P. Borovikovskiy and proposed his own approach to delimitation of the analysed concepts. He defined several criteria for the land parcel and subsoil delimitation: "the availability of mineral deposits in subsoil and the target purpose of works", and expressed confidence that it would be expedient to adhere to the given criteria in the future $[2$, p. 15,16$]$.

The current natural resources law delimitates subsoil and land parcel not so much by a dimensional sign while defining subsoil as a part of the earth crust located under a soil layer and, if it is not available - lower than the earth surface, but by a functional sign, which has to be understood as an object target use.

This is confirmed by Art. 6 of the Law "On Subsoil" regulating the types of subsoil use and Art. 7 of the RF Land Code differentiating the lands by their intended use. Pursuant to the foregoing provisions of the law, the subsoil and a land parcel are not the objects that replace one another sequentially in space, but the objects each of which occupies its own place in production activities. Therefore, the attitude toward the use of subsoil and land are different above all by content.

Such understanding of natural resources does not stay within the habitual concept of an item 
requiring a precise geometrical definition. The latter means the necessity to consider specifics of natural resources when they are individualized as subject matters of the right and, in particular, of civil transactions. However, this issue needs to be specially investigated and cannot be covered by this article to full extent.

When it comes to the issue of a land user's right to underground space, it is possible to formulate the following general rule: a land parcel user has a right to use underground space to the depth needed for appropriate utilization of land according to the intended purpose. Construction activities take specific place among the types of intended purpose of land use, and in relation to constructions a lawmaker has set up a specific requirement which will be discussed below.

\section{The Rights of Land Parcel Users}

to Use Widespread Mineral Deposits,

\section{Groundwater and to Construct Underground}

Facilities for Their Own Needs and within the Boundaries of the Given Land Parcels

The legislation branches related to natural resources specifically regulate issues that have to do with the rights of land users to use widespread mineral deposits and groundwater and to make construction of underground facilities for their own needs and within the boundaries of given land parcels.

\section{The Use of Widespread Mineral Deposits}

The widespread mineral deposits have been in the law as a kind of mineral deposits since the first years of the Soviet regime. From the very beginning, the specificity of economic use and abundance of minerals across the territory of the country has served as a criterion for grouping of mineral deposits [3, p. 9].

The effective version of Art. 19 of the RF Subsoil Law sets forth that within boundaries of given land parcels and without blasting works the land parcel owners, land users, landholders, and land tenants are entitled to use for their own needs, widespread mineral deposits which may be available within the land boundaries and are not recorded in the State Register of Mineral Reserves. The use of widespread mineral deposits for own needs is interpreted to mean that they are used by land parcels owners, land users, landholders, and land tenants for personal, household and other needs and are not associated with business activities.

How should the right to use widespread mineral deposits be qualified? Modern researchers have different answers to this question. According to O. I. Kotova "granting the right to land owners, holders to extraction of $\mathrm{WMD}^{1}$ for their own needs can be considered as a specific benefit offered by the State to land parcel owners, holders, and as an authority to get benefits from a land parcel owned or held, because extracted WMD are bedded superficially (at the depth of up to 5 meters). This authority may be deemed to be a relic of the right of accession according to which a landowner was entitled to extract all natural resources deposited within the parcel boundaries" [8, p. 23, 24].

If to agree with the foregoing opinion, the widespread mineral deposits should be considered as a part of the land parcel, which is contrary to provisions of Art. 6 of the Subsoil Law which says that extraction of mineral deposits is one of the types of subsoil use. Use of widespread mineral deposits by a land parcel user is also a type of subsurface management, which is based, as in the Soviet time, on a permit issued by the State allowing for utilization of some natural resources wherein the State acts as a mineral owner.

According to P. M. Khodyrev "the right to extraction of widespread mineral deposits is a specific limited proprietary right, which is interlinked with the right of ownership and use of land, and, per se, makes it as an attribute of land parcel" [11, p. 23].

This position is deemed to be controversial. The complexity in identification of the right to use widespread mineral deposits is caused by the fact that such right does not comply with the norms of the RF Civil Code. For this reason, it cannot be directly attributed to any type of the right known to the civil law.

\footnotetext{
${ }^{1}$ WMD means widespread mineral deposits (author's note).
} 
This right is neither qualified in the draft Civil Code of the Russian Federation. Art. 296.8 of the draft states that "a land parcel owner's rights to subsoil block located under the land parcel are defined in this Code and the subsoil law, including the right to extraction of widespread mineral deposits and fresh groundwater to be used for own needs"1. The planned revision of the civil legislation with regard to the analysed issue is nothing but reproduction of the mining legislation and does not match with proprietary qualification (identification) of the right to extraction of widespread mineral deposits and groundwater (in the terms of previous version of Art. 19 of the Subsoil Law).

However, such aspects as observance and following from the law and personal nature of use (not for business purposes) make the right to use widespread mineral deposits closer to the right of common natural resources management specified in the environmental law.

The right to use widespread mineral deposits arises and ceases to exist simultaneously without any permissions together with origination and termination of the land title, respectively. The literature contains an opinion that "extraction of widespread mineral deposits allowed to every land parcel owner, landholder, land user and land tenant should not be the only purpose of land use, but may just accompany the use of land parcel as intended provided that the land law requirements are complied with" [11, p. 24].

This approach should be accepted at least because the failure to use the land parcel as intended means that its user has no "his own needs", though the law provides for the right to use widespread mineral deposits exactly for these needs to be satisfied.

In this regard the Decision of the Federal Arbitration Court of the Central District of dated April 2, 2014 in the case No. A23-2133/2013 is very exemplary, because this Decision refused to satisfy a claim wherein it was requested to invali-

\footnotetext{
${ }^{1}$ On introduction of changes to Parts 1, 2, 3, and 4 of the Civil Code of the Russian Federation and to some bylaws of the Russian Federation: Draft Federal Law No. 47538-6 (version passed by SD FA RF in its first reading on 27.04.2012). [Electronic resource]. Access from "ConsultantPlus".
}

date and void an order of a competent authority to remedy and correct violation of the land law. In the course of this case, the court determined that the land law compliance verification procedure held by the competent authority found that the land was used for the purposes other than farming, and that there was a pit to extract sand for construction of a car-racing track. The pit covered 1 hectare of the described land plot, and its depth was 5-6 m, that soil deposit area was all along the pit perimeter and that concrete slabs made up an access road of $400 \mathrm{~m}$ in length and $15 \mathrm{~m}$ in width, and the removed topsoil was placed to the right and to the left from the road.

Pursuant to the submitted documents, the Company is a land tenant, this land parcel is qualified as agricultural land with the permitted use to be farming. At the same time, the Company, as a tenant of the rented land, uses it for purposes other than farming.

Based on Part 1 of Art. 8.8 of the Administrative Code of the Russian Federation, the Company was subject to administrative penalties. Moreover, an improvement notice was sent to the Company wherein it was ordered to correct found violations of land law.

In its application to make an order of a competent authority to remedy and correct violation of the land law invalid and null, the Company referred to the fact that it is entitled to use land parcel for the purposes other than farming with due regard to rules defined in Article 19 of the RF Subsoil Law of 21.02.1992 No. 2395-1.

The Cassation Court agreed with the opinion of lower courts and stated that compliance with requirements with other regulations, including subsoil law does not exclude the binding nature of the land legislation provisions ${ }^{2}$.

In the earlier version of Art. 19 of the RF Subsoil Law land parcel owners, land users, landholders, and land tenants had a right to be involved in extraction of widespread mineral deposits for their own needs.

\footnotetext{
${ }^{2}$ Award of FAC in the Central District of 02.04.2014 in a case No. A23-2133/2013 [Electronic resource]. Access from "ConsultantPlus".
} 
In our opinion, the law applies to the term extraction of widespread mineral deposits broadly covering not only extraction of mineral deposits from the subsoil or separation from the subsoil, but further use of mineral deposits for own needs.

However, some court rulings or orders contain another narrow interpretation of extraction of widespread mineral deposits in the context of the earlier version of Art. 19 of the Subsoil Law. For example, by the Decision of the Arbitration Court of Novgorod Region of 25.11.2008 in the case No. A44$3570 / 2008$, the administrative penalty on the limited liability company (the "Company") imposed by the competent authority's (the "Administration") was declared illegal and was cancelled. The court determined that the Company and an individual using the land parcel entered into a contract according to which the Company undertook to make an excavation, and the ground (sand) from a dug hole was to be transferred into the Company's ownership. According to the court opinion, "the Administration's argument that according to Art. 19 of the Subsoil Law the right of land users to extraction of widespread mineral deposits within the boundaries of their land parcels may arise only if such mineral deposits are used as mineral deposits for their own needs, is inconsistent". The court also held that "the Administration's argument that the subsoil plots cannot be a subject matter of civil transactions conflicts with the circumstances established in the case, because in this context it is not the subsoil plot, but widespread mineral deposits (sand) that are the subject matter of transactions"1.

The Court of Appeal supported the trial court's position and pointed out that Art. 19 of the Subsoil Law "does not contain conditions necessary to qualify the use of extracted mineral deposits as for own needs".

Most likely, in order to preclude from similar interpretation of Art. 19 of the Subsoil Law, the legislator not only refused from using the term extraction of widespread mineral deposits and re-

\footnotetext{
${ }^{1}$ Award of the Court of Arbitration in Novgorod Region of 25.11.2008 in a case N A44-3570/2008 [Electronic resource]. Access from "ConsultantPlus".

${ }^{2}$ Award of the $14^{\text {th }}$ Arbitration Court of Appeal of 22.01.2009 in a case No. A44-3570/2008 [Electronic resource]. Access from "ConsultantPlus".
}

placed it with the use of widespread mineral deposits, but additionally established that widespread mineral deposits found within the land boundaries and used by the land parcel owners, land users, landholders, and land tenants for personal, household and other needs not associated with commercial purposes, cannot be alienated or transferred from one person to another (Art. 19 of the Subsoil Law).

In our opinion, the above-mentioned replacement of terminology does not reflect the legislator's new approach to definition of the scope of land parcel user's rights to widespread mineral deposits. It is apparent that natural resources can be used only when they have been earlier extracted, that, indeed, from the viewpoint of land user's rights, means that extraction of widespread mineral deposits (in the earlier terminology) and use of widespread mineral deposits (in the current terminology) are identical.

\section{The Use of Groundwater}

The Russian Federation is on the list of countries with rich water resources. The groundwater resource potential on the territory of the Russian Federation makes up approx. $400 \mathrm{~km}^{3}$ per year. The total reserve of groundwater that may be used (for human consumption, for household, for production and technical purpose, for irrigation of lands and livestock water development) is around $34 \mathrm{~km}^{3}$ per year ${ }^{3}$.

Groundwater serves as an independent asset, which can be used under the state control separately from any other natural wealth. Foreign researchers note that groundwater is the most extractable natural resource in the world. Groundwater provides more than half of humanity with fresh water for daily use, including potable water supply, for cooking, for hygienic purposes, and irrigation [14].

In the current version of Art. 19 of the Subsoil Law the land parcel users have the right to use for their own needs groundwater which may be available within the land boundaries of their land provided that the extracted water should not exceed $100 \mathrm{~m}^{3}$ per day from water-bearing horizons which do not feed centralized water supply systems,

\footnotetext{
${ }^{3}$ Water strategy of the Russian Federation for the period up to 2020: approved by the Edict of the Government of the Russian Federation of 27.08.2009 N 1235-p. LC RF. 07.09.2009. No. 36. Art. 4362.
} 
and should be located above the water-bearing beds which are sources of centralized water supply ${ }^{1}$.

It is worth mentioning that special rights of a land owner to groundwater are stipulated by the legislation of many countries [20].

The Russian legislator has conditioned the use of groundwater for own needs, which means personal, household and other needs not associated with commercial activities, without specifying what these needs exactly mean. Should they be interpreted as any needs not associated with carrying out of business activities? Can a businessman have these such needs (and what are they)? Is it possible, in particular, to attribute individual needs of legal entities in groundwater to such needs?

At present, judicial practice shows that unlicensed use of groundwater by legal entities for utility purposes is possible. For example, Ruling No. 17AP-17116/2016-AK dd. 21.12.2016 of the $17^{\text {th }}$ Arbitration Court of Appeal under case No. A50-22673/2016 satisfied a claim to set aside the decision of administrative sanctions imposed for the unlicensed use of subsoil. When reviewing the case, the court determined that the Perm State University was administratively liable for groundwater extraction without a subsoil use licence.

In its application for invalidation and cancellation of the decision of imposition of administrative penalty the University pointed out that the groundwater from a well located on the land parcel owned by the University was extracted for its own needs, i.e. for household practical use at the academic training facility. Groundwater extracted from water-bearing beds that never supplied the centralized water system made up $100 \mathrm{~m}^{3}$ per day.

The trial court satisfied the University's application and commented that "the administrative body submitted no facts that might evidence non-

\footnotetext{
${ }^{1}$ In the earlier version of Art. 19 of the Law "On Subsoil" the right for extraction of groundwater was expressed by means of pointing to the possibility of organization and maintenance of domestic pits and wells on first water-bearing bed and which are not the sources of centralized water supply according to the procedure established by the government authorities of the constituents of the Russian Federation.
}

compliance with the conditions provided for in Art. 19 of RF Subsoil Law No. 2395-1 dd. February 21, 1992 during groundwater extraction (the information from the tax service was not subject to verification, the daily volume of produced water was not identified; circumstances confirming that the water was extracted from the water-bearing horizons, which source the centralized water supply and are located above the water-bearing beds supplying the centralized water system, were not investigated; facts and eventual purposes of the well use were not checked)".

The Court of Appeal supported conclusions of the trial court and additionally noted the following: references of the administrative body given in the appeal petition that the University has a right to run business on the basis of the Charter, do not confirm that in this particular case the groundwater was extracted for business purposes ${ }^{2}$.

Thus, carrying out business activities (as well as a right to run such activities in the manner prescribed by the law) leaves the possibility of the unlicensed use of groundwater open.

Admitting the possibility for use of groundwater by legal entities, we believe that it is necessary to differentiate between purposes of groundwater use for individuals and legal entities, because the needs of the latter would be hardly to name as personal and household needs. If groundwater is used by other land parcel users but not individuals, the purposes of their use could be named as economic needs provided that these needs are not beyond the limits of non-production field.

Foreign legislation admits the possibility for the unlicensed use of groundwater by legal entities, e. g., for water for employees, watering of lawns [22].

The right to groundwater use cannot be directly attributed to any right known to the civil law. Difficulties associated with qualifications of the

\footnotetext{
${ }^{2}$ Award of the $17^{\text {th }}$ Arbitration Court of Appeal of 21.12.2016 N 17АП-17116/2016-AK in a case No. A50-22673/2016 [Electronic resource]. Access from "ConsultantPlus".
} 
right to groundwater exist in other countries. For example, the right to groundwater in California as opposed to the land title has a limited and undefined nature [16]. In Texas, since 1840, from the moment of adoption of the English common law as a part of the First Constitution of Texas, groundwater has been considered to be a part of land parcel, and a landowner has been deemed to be its absolute owner. However, nowadays many people demonstrate adherence to another approach, and they believe that the right to groundwater should be qualified as a usufruct [18].

Foreign researchers note that "the rights to groundwater lose connotations of private ownership" [13]. Groundwater is not considered anymore as a private wealth associated with a right to land parcel, but it is deemed to be a public benefit [17, p. 12].

Taking the foregoing into consideration, we assume that the Russian legislation with regard to the use of groundwater barely needs seeking the civilised concepts for identification of that right (correlation with the RF Civil Code). Regulation of the mentioned relations is quite acceptable also within the frames of the common natural resources management law. The specified concept made it possible for the legislator to set up limits and purposes of groundwater use (in the current version), which would be problematic to achieve within the frames of civil legislation.

Ensuring of the state control and supervision over purposes and consumption of groundwater volumes by land users should become an urgent issue.

\section{Construction of Underground Facilities}

Landholders have the right to carry out constructions of underground facilities to the depth of 5 meters within the boundaries of their land parcels.

According to the general rule set forth in Part 4 of Art. 7 of the Subsoil Law a subsoil user, who has a mining allotment, has an exclusive right to use the subsoil within the boundaries in conformity with a license he/she has obtained. Any activity related to the use of subsoil within the boundaries of a mining allotment can be carried out only upon a consent of the subsoil user who is entitled to this mining allotment.

As it follows from Ruling No. 1314-O of the RF Constitutional Court dd. 24.06.2014, an exclusive right to use the subsoil should be understood as follows “...the right not to let any other persons use his / her granted mining allotment as well as the right to demand not to hinder execution of his / her rights and performance of obligations associated with the subsoil use"1.

Is the land parcel user's right to construction of underground facilities being exclusive in the foregoing context? Theoretically, there are no any practical grounds to give a negative answer to the question raised. As to the practice of resolution of disputes arisen in connection with the underground space protection by land parcel (surface) users, the courts demonstrate different approaches to resolution of the analysed issue.

The dispute of elimination of obstacles in use of land parcel by means of vesting a defendant with an obligation to erect the wall in the basement of a garage belonging to him, along the boundary of land parcels of a plaintiff and a defendant is of interest ${ }^{2}$.

In the case under review, it was found out that a plaintiff and a defendant were the owners of adjacent land parcels on which residential and nonresidential facilities are located, including garages. Moreover, the defendant organized a basement in his garage in such a way that it stretched further than the limits of the land owned by the defendant and was, partly, under the garage of the plaintiff on the plaintiff's land.

The court satisfied the plaintiff's claim and pointed out that the use by the defendant of space under the surface of the plaintiff's land parcel is illegal and interferes with the rights and lawprotected interests of the plaintiff, because such use hinders the plaintiff from use of that space at own and sole discretion.

At the same time, there are such examples when courts demonstrate another approach. For example, the Decision of the Federal Arbitration Court in Povolzhskiy District of 19.07.2012 under case No. A55-27370/2010 rejected a claim to bind and compel a defendant to dismantle a heat outlet of heating pipe main and to bring land parcels to the original state. In the course of the case review

\footnotetext{
${ }^{1}$ On refusal to accept for consideration a complaint of Kirpichnyi Ltd. and Khalenkov Arthur Vasilievich, a citizen, of abuse of constitutional rights and freedoms with part 7 of Article 7 of the Russian Federation Law "On Subsoil": Determination of the RF Constitutional Court of 24.06.2014 No. 1314-O [Electronic resource]. Access from "ConsultantPlus".

${ }^{2}$ Determination of the RF Supreme Court of 02.06.2015 N 4КГ15-19 [Electronic resource]. Access from "ConsultantPlus".
} 
it was found out that the plaintiff owned two land parcels on which a defendant's heating main ran (at the depth of 0.98 to $1.72 \mathrm{~m}$ ).

Satisfying the plaintiff's claims and vesting the defendant with an obligation to free the part of a plaintiff's land from the pipeline the trial court and the appeal court concluded that the defendant had no any lawful grounds to lay out pipeline on that part of the plaintiff's land parcel and that there is no proof of the fact of violation of rights and lawful interests of the plaintiff in the use of the disputed land.

The Cassation Court cancelled the orders of lower courts motivating that placement of the pipeline at the depth of land parcel owned by the plaintiff does not prevent the use of lands within the limits determined by its intended use - for farming.

In the cassation opinion, when vesting the defendant with an obligation to free the land parcel from the heating pipe main, the courts did not consider a principle of proportionality of taken liability and committed violation. It proceeds from the case files that dismantling of the heat outlet will result in disturbance of the circular heat supply system and impossibility to use it. Consequently, the remedy of violated right applied by courts does not comply with the principle of proportionality of the remedy of the plaintiff's right to remove obstacles for the use of land parcel ${ }^{1}$.

In the case outlined above, the court analyzed the dispute only in terms of the needed "depth" for the use of land parcel as intended, and ignored another aspect of the underground space use within the boundaries of land parcels belonging to the plaintiff: the plaintiff's right o construction of underground facilities according to the procedure set forth in Art. 19 of the Subsoil Law. It is evident that the court took a decision on the appropriate remedy focusing on social importance of the disputed object.

Having refused in satisfaction of plaintiff's claim to dismantle the heat outlet located within the plaintiff's land boundaries, the court satisfied the plaintiff's claim relating to another dispute by recovering damages in connection with the loss of

\footnotetext{
${ }^{1}$ Award of Federal Court of Arbitration in Povolzhskiy District of July 19, 2012 in a case No. A55-27370/2010 [Electronic resource]. Access from "ConsultantPlus".
}

land value. According to court opinion, this is the only possible method of restoration of rights ${ }^{2}$ in the case. Thereby, to our mind, the court indirectly confirmed the plaintiff's right to the land parcel in relation to that part (depth) which is beyond the limits required for its proper use as intended.

Notwithstanding the difference in approaches to defense of the underground space in the abovementioned judicial acts, the right to underground space in every judicial act was considered as a right to the land parcel, to its specific "underground" part. These acts do not contain analysis of land parcel user's rights to the subsoil that would cover underground constructions according to the procedure set forth by Art. 19 of the Subsoil Law

Meanwhile, as we believe, it is this rule of law that determines the land user's right to the land parcel, in particular not to the "underground space" in certain volume, but to construction of underground facilities.

Therefore, the present question is whether the right to construction of underground facilities is applicable to lands of all categories and types of permitted use? In particular, whether the users of agricultural land within the boundaries of which the legislator bans any construction as per general rule, have such a right? Under this approach, where the land parcel is nothing but a "flat" object with evidently expressed functional nature of its use, there are no any grounds to entitle all land users to make constructions of underground facilities irrespective of the purpose of use of a certain land parcel. If the legislator prohibits any construction on a land parcel, first of all, this concerns agricultural lands, so, the possibility of underground construction is doubtful. This also means that there are reasons or grounds for defence of underground space within the land boundaries, if it is not beyond the limits needed for the use of land parcel as intended.

As to construction of underground facilities, according to the procedure set forth in Art. 19 of the Subsoil Law, the legislator does not explain their functional purpose. Should such underground facilities be of auxiliary nature only, i. e. there should be a main building or facility on the

\footnotetext{
${ }^{2}$ Determination of the RF Supreme Court of 28.02.2017 No. 306-ЭC16-21445 in a case No. A55-2910/2014 [Electronic resource]. Access from "ConsultantPlus".
} 
concerned land in relation to which the underground facility has an auxiliary or servicing function? Could these facilities be relatively independent, with no main building on the land parcel? May these underground parts of buildings which according to the Technical Regulation on Safety of Buildings and Facilities ${ }^{1}$, be deemed eventual parts of buildings, underground facilities within the frames of Art. 19 of the Subsoil Law?

Moreover, should underground facilities be constructed at the depth of up to 5 meters by users of land parcels for their own needs exclusively? May a land parcel user give his/her consent to another party for the use of underground space?

It is necessary to answer these questions in order to outline and to develop relations within the use of underground space. Foreign researchers are sure that "it is obvious that cities have faced a problem of "growth ceiling" and require innovation strategies of development and stable renewal and upgrading to the benefit of compact city patterns" [21].

One of the promising directions is development of underground space, which is the specific concern of major cities. Such development is impossible without precise defining and fixing of the land users' right to the underground space in general and to construction of underground facilities in particular.

\section{Conclusions}

The current law offers two different approaches to solving the issue of the user's rights to underground space: the civil law approach, based on the principle of cujus est solum, and the natural resource approach, providing access to natural resources based on the right to common natural resources management.

According to the latter approach, a land user may use underground space in two ways: use it within the limits required for proper use of land parcel as intended and use the underground space as a subsoil according to Art. 19 of the Subsoil Law.

\footnotetext{
${ }^{1}$ Technical Regulation on Safety of Buildings and Constructions: Federal Law of 30.12.2009 No. 384-Ф3 (version of 02.07.2013). Legislative Corpus of the Russian Federation. 2010. No. 1, Art. 5.
}

The natural resource approach does not leave space for application of Clause 3 of Art. 261 of the RF Civil Code. Foreign scholars assume that it is a problem to apply the cujus est solum principle. According to them, at present this principle is misleading and ambiguous [15]. In particular, the scope of its application is unclear, so this principle will slow down the development of natural resources and definitely cause damage to the national interests [12].

Taking into consideration the foregoing, it is the natural resources law that will shape up the base for building up relations within the use of underground space.

\section{References}

1. Anisimov A. P., Charkin S. A. Ob"ekty zemel'nykh pravootnosheniy [Objects of Land Relations]. Rossiyskaya yustitsiya - Russian Justitia. 2012. Issue 2. Pp. 4-8. (In Russ.).

2. Bashmakov G. S. Pravo pol'zovaniya nedrami v SSSR [The Right of Subsoil Use in the USSR]. Moscow, 1974. 156 p. (In Russ.).

3. Bashmakov G. S. Pravovoe regulirovanie razvedki $i$ razrabotki obshcherasprostranennykh poleznykh iskopaemykh [Legal Regulation of Exploration and Exploitation of Commonly Occurring Mineral Resources]. Moscow, 1978. 136 p. (In Russ.).

4. Borovikovskiy A. L. V sude i o sude. III: Pravo na «nedra» zemli [In the Court and about the Court. III: The Right to the "Bowels" of the Earth]. Zhurnal Ministerstva yustitsii - Journal of the Ministry of Justice. St. Petersburg, 1897. Issue 8 (October). Pp. 79-90 (In Russ.).

5. Dimitriev M. A. K voprosu ob uchastkakh nedr kak ob"ektakh grazhdanskikh prav [On the Issue of Plots of Subsoil as Objects of Civil Rights]. Rossiyskiy sud'ya - Russian Judge. 2011. Issue 12. Pp. 17-20. (In Russ.).

6. Kalinichenko K. S. Pravovoy rezhim zemel'nogo uchastka $i$ raspolozhennykh na nem zdaniy, sooruzheniy $v$ Rossii $i$ Germanii: avtoref. diss. ... kand. yurid. nauk [Legal Regulation of Land Plots and Buildings Located on Them in Russia and Germany: Synopsis of Cand. jurid. sci. diss.]. St. Petersburg, 2016. 22 p. (In Russ.).

7. Kamyshanskiy V.P. O prave pol'zovaniya uchastkami nedr $v$ nauke grazhdanskogo prava [To the Issue of the Right of Bowels' Sites Usage in the Science of Civil Law]. Vlast' 
Zakona - The Reign of Law. 2016. Issue 2. Pp. 15-21. (In Russ.).

8. Kotova O. I. Pravovoe regulirovanie osvoeniya mestorozhdeniy obshcherasprostranennykh poleznykh iskopaemykh: avtoref. diss. ... kand. yurid. nauk [Legal Regulation of Development of Deposits of Commonly Occurring Minerals: Synopsis of Cand. jurid. sci. diss.]. Moscow, 2007. 29 p. (In Russ.).

9. Lapach V.A. Sistema ob"ektov grazhdanskikh prav: Teoriya i sudebnaya praktika [The System of Objects of Civil Rights: Theory and Judicial Practice]. St. Petersburg, 2002. 544 p. (In Russ.).

10. Udintsev V. Russkoe gornozemel'noe pravo [Russian Mining Right]. Kiev, 1909. 373 p. (In Russ.).

11. Khodyrev P. M. Pravo sobstvennosti na poleznye iskopaemye: avtoref. diss. ... kand. yurid. nauk [Proprietary Right to Minerals: Synopsis of Cand. jurid. sci. diss.]. Izhevsk, 2008. 25 p. (In Russ.).

12. Bradbrook A. J. The Relevance of the Cujus Est Solum Doctrine to the Surface Landowner's Claims to Natural Resources Located Above and Beneath the Land. Adelaide Law Review. 1988. Vol. 11. No. 4. Pp. 462-483. (In Eng.).

13. Burchi S., Nanni M. How Groundwater Ownership and Rights Influence Groundwater Intensive Use Management. Intensive Use of Groundwater: Challenges and Opportunities. Llamas and Custodio (eds.), Balkema Publishers. The Netherlands, 2003. Pp. 22-7240. (In Eng.).

14. Gabriel E. Eckstein. Commentary on the U. N. International Law Commission's Draft Articles on the Law of Transboundary Aquifers. Available at: http://scholarship.law. tamu.edu/facscholar/52 (accessed 22.08.2017). (In Eng.).

15. Griggs L. D., Snell R. Property Boundaries and Incidental Rights Attached to the Ownership of Land in Tasmania. University of Tasmania Law Review. 1991. Vol. 10. No. 3. Pp. 256-268. (In Eng.).

16. Groundwater Managed: California Takes its First Step Towards Groundwater Sustainability. Available at: http://www.sjcl.edu/images/ stories/sjalr/volumes/V25N1C1.pdf (accessed 17.08.2017). (In Eng.).

17. Hodgson S. Modern Water Rights. Theory and Practice. Food and Agriculture Organization of the United Nations. Rome. 2006. 116 p. (In Eng.).
18. Marvin W.J., Little A. The Ownership of Groundwater in Texas: a Contrived Battle for State Control of Groundwater. Available at: http://www.texasgroundwaterlaw.com/Upload/ baylorlawreview_groundwaterownership.pdf (accessed 17.08.2017). (In Eng.).

19. Mechlem K. Groundwater Governance: The Role of Legal Frameworks at the Local and National Level-Established Practice and Emerging Trends. Available at: http://creativecommons.org/licenses/by/4.0/ (accessed 17.08.2017). (In Eng.).

20. Oklahoma Groundwater Law Handbook. Available at: http://osufacts.okstate.edu/docushare/dsweb/Get/Document-7068/ (accessed 06.06.2013) (In Eng.).

21. The Way to Plan a Sustainable "Deep City": From Economic and Strategic Aspects. Available at: http://www.corp.at/archive/CORP 2012_82.pdf (accessed 17.08.2017). (In Eng.).

22. Water Rights Workshop. Oklahoma Governor's Water Conference \& Research Symposium. October 26-27, 2010. Available at: https:// www.owrb.ok.gov/gwc/presentations/2010/OW RB_WaterRights1.pdf (accessed 17.08.2017). (In Eng.).

\section{References in Russian}

1. Анисимов А. П., Чаркин С. А. Объекты земельных правоотношений // Российская юстиция. 2012. № 2. С. 4-8.

2. Башмаков Г. С. Право пользования недрами в СССР. М.: Наука, 1974. 156 с.

3. Башмаков Г. С. Правовое регулирование разведки и разработки общераспространенных полезных ископаемых. М.: Наука, 1978. $136 \mathrm{c}$.

4. Боровиковский А. Л. В суде и о суде. III: Право на «недра» земли // Журнал Министерства юстиции. СПб., 1897. № 8. C. 79-90.

5. Димитриев М. А. К вопросу об участках недр как объектах гражданских прав // Российский судья. 2011. № 12. С. 17-20.

6. Калиниченко K. C. Правовой режим земельного участка и расположенных на нем зданий, сооружений в России и Германии: автореф. дис. ... канд. юрид. наук. СПб., 2016. 22 c.

7. Камышанский В. П. О праве пользования участками недр в науке гражданского права // Власть закона. 2016. № 2. С. 15-21.

8. Котова О. И. Правовое регулирование освоения месторождений общераспространен- 
ных полезных ископаемых: автореф. дис. ... канд. юрид. наук. М., 2007. 29 с.

9. Лапач В.А. Система объектов гражданских прав: Теория и судебная практика. СПб., 2002. $544 \mathrm{c}$.

10. Удинцев В. Русское горноземельное право. Киев, 1909. 373 с.

11. Ходырев П. М. Право собственности на полезные ископаемые: дис. ... канд. юрид. наук. Ижевск, 2008. 25 с.

12. Bradbrook A. $J$. The relevance of the cujus est solum doctrine to the surface landowner's claims to natural recources located above and beneath the land // Adelaide Law Review. 1988. Vol. 11, № 4. Pp. 462-483.

13. Burchi S., Nanni M. How Groundwater Ownership and Rights Influence Groundwater Intensive Use Management // Intensive Use of Groundwater: Challenges and Opportunities. Llamas and Custodio (eds.), Balkema Publishers. The Netherlands, 2003. Pp. 227-240.

14. Eckstein G. E. Commentary on the U.N. International Law Commission's Draft Articles on the Law of Transboundary Aquifers. URL: http://scholarship.law.tamu.edu/facscholar/52 (дата обращения 22.08.2017).

15. Griggs L. D., Snell R. Property boundaries and incidental rights attached to the ownership of land in Tasmania // University of Tasmania Law Review. 1991. Vol. 10, № 3. Pp. 256-268.
16. Groundwater managed: California takes its first step towards groundwater sustainability. URL: http://www.sjcl.edu/images/stories/sjalr/volumes /V25N1C1.pdf (дата обращения: 17.08.2017).

17. Hodgson S. Modern water rights. Theory and practice. Food and Agriculture Organization of the United Nations. Rome. 2006. 116 p.

18. Marvin W.J., Little A. The ownership of groundwater in Texas: a contrived battle for state control of groundwater. URL: http://www. texasgroundwaterlaw.com/Upload/baylorlawreview_groundwaterownership.pdf (дата обращения: 17.08.2017).

19. Mechlem K. Groundwater Governance: The Role of Legal Frameworks at the Local and National Level-Established Practice and Emerging Trends. URL: http://creativecommons.org/ licenses/by/4.0/ (дата обращения: 17.08.2017).

20. Oklahoma Groundwater Law Handbook. URL: http://osufacts.okstate.edu/docushare/ds web/Get/Document-7068/ (дата обращения: 06.06.2013).

21. The Way to Plan a Sustainable "Deep City": From Economic and Strategic Aspects. URL: http://www.corp.at/archive/CORP2012_82.pdf (дата обращения 17.08.2017).

22. Water Rights Workshop. Oklahoma Governor's Water Conference \& Research Symposium October 26-27, 2010. URL: https://www.owrb. ok.gov/gwc/presentations/2010/OWRB_Water Rights1.pdf (дата обращения: 17.08.2017). 